\title{
Effects of substituting ytterbium for scandium on the microstructure and age-hardening behaviour of Al-Sc alloy
}

\author{
N.Q. Tuan ${ }^{\text {a,* }}$, A.M.P. Pinto ${ }^{\text {a }}$, H. Puga ${ }^{a}$, L.A. Rocha ${ }^{\mathrm{a}, \mathrm{b}}$, J. Barbosa ${ }^{\mathrm{a}}$ \\ ${ }^{a}$ CT2M - Centre for Mechanical and Materials Technologies, University of Minho, Azurém, 4800-058 Guimarães, Portugal \\ ${ }^{\mathrm{b}}$ Universidade Estadual Paulista (Unesp), Faculdade de Ciências de Bauru, SP 17033-360, Brazil
}

\section{A R T I C L E I N F O}

\section{Article history:}

Received 11 December 2013

Received in revised form

12 February 2014

Accepted 14 February 2014

Available online 20 February 2014

Keywords:

Aluminium-scandium alloys

Ytterbium

Age-hardening

Precipitate coarsening

TEM

High-resolution TEM

\begin{abstract}
A B S T R A C T
In order to reduce the cost of $\mathrm{Al}-\mathrm{Sc}$ alloys and maintain their mechanical properties, the microstructure and mechanical properties of $\mathrm{Al}-0.24 \mathrm{wt} \% \mathrm{Sc}-0.07 \mathrm{wt} \% \mathrm{Yb}$ in comparison with $\mathrm{Al}-0.28 \mathrm{wt} \% \mathrm{Sc}$ alloys were studied. The aging behaviour, precipitate morphologies, precipitate coarsening and precipitation hardening of both alloys were investigated. The average diameter and the size distribution of nanoscale $\mathrm{Al}_{3} \mathrm{Sc}$ and $\mathrm{Al}_{3}(\mathrm{Sc}, \mathrm{Yb})$ precipitates at various aging conditions were measured. Transmission electron microscopy (TEM) and high-resolution TEM were used to deeply understand the precipitate evolution. A maximum hardness around $73\left(\mathrm{HV}_{30}\right)$ was obtained with a precipitate diameter from 4.3 to $5.6 \mathrm{~nm}$ for both alloys.
\end{abstract}

(c) 2014 Elsevier B.V. All rights reserved.

\section{Introduction}

Al-Sc alloys have excellent mechanical properties at ambient and elevated temperatures due to the presence of a high number density (as high as $10^{22} \mathrm{~m}^{-3}$ ) of elastically-hard $\mathrm{Al}_{3} \mathrm{Sc}$ ( $\mathrm{L}_{2}$ structure) precipitates [1-4]. The $\mathrm{Al}_{3} \mathrm{Sc}$ precipitates remain fully coherent with the $\alpha$-Al matrix at elevated temperatures $[1,5]$. Among alloying elements of $\mathrm{Al}$ alloys, Sc has one of the greatest strengthening effects on a per-atom basis [6]. The $\mathrm{Al}_{3} \mathrm{Sc}$ precipitates are very stable with respect to coarsening, even for long aging times at $350{ }^{\circ} \mathrm{C}$ [1], while in commercial age-hardening $2 \mathrm{xxx}$ and $6 \mathrm{xxx}$ series alloys containing $\mathrm{Cu}, \mathrm{Mg}$ and $\mathrm{Si}$, the precipitates coarsen rapidly at temperatures above $250{ }^{\circ} \mathrm{C}$ [6]. At ambient temperature the lattice parameters of $\mathrm{Al}$ and $\mathrm{Al}_{3} \mathrm{Sc}$ are 0.40496 and $0.4105 \mathrm{~nm}$, respectively, showing a small lattice parameter mismatch of $\mathrm{Al}_{3} \mathrm{Sc}$ precipitates with the $\alpha$-Al matrix [7-9]. A good interfacial strength between the $\mathrm{Al}_{3} \mathrm{Sc}$ precipitates and the $\alpha-\mathrm{Al}$ matrix will hinder dislocation motion and prevent grain growth [10]. In addition, the high thermal stability of the $\mathrm{Al}_{3} \mathrm{Sc}$ precipitates will improve the strength of these alloys at high temperature $[11,12]$. Therefore Al-Sc alloys are widely used in the fabrication of sports equipment, aerospace components and in a range of structural applications.

\footnotetext{
* Corresponding author. Tel.: + 351253510220 ; fax: + 351253516007.

E-mail address: quoctuan1884@gmail.com (N.Q. Tuan).
}

Although Al-Sc alloys are very attractive, their use is limited by the cost and availability of Sc. A possible solution for this problem could be replacing part of the Sc content by other alloying elements similar in nature in order to reduce the Sc content without decreasing properties. Among them, rare-earth metals (REMs) are attractive ternary additions to substitute Sc, showing some interesting characteristics/benefits: (i) many REMs substitute $\mathrm{Sc}$ in the $\mathrm{Al}_{3} \mathrm{Sc}$ precipitates forming $\mathrm{Al}_{3}\left(\mathrm{Sc}_{1-x} \mathrm{REM}_{x}\right)\left(\mathrm{L}_{2}\right.$ structure) with high solubility $[13,14]$; (ii) the light REMs have a smaller diffusivity in Al than Sc [15], improving the coarsening resistance of the precipitates; (iii) REMs increase the lattice parameter mismatch between $\alpha-\mathrm{Al}$ and $\mathrm{Al}_{3}\left(\mathrm{Sc}_{1-x} \mathrm{REM}_{x}\right)[13,14]$, which could increase the creep resistance of the alloy [16]; (iv) most of the REMs have electronegativity values very similar to Sc suggesting that these metals should strongly resemble $\mathrm{Sc}$ in their interaction with $\alpha$-Al. The metallic radii of all REMs are significantly larger than Sc leading to an increasing of the lattice parameter mismatch between $\alpha-\mathrm{Al}$ and $\mathrm{Al}_{3}\left(\mathrm{Sc}_{1-x} \mathrm{REM}_{x}\right)$. Karnesky et al. [17] showed that the Vickers hardness of Al-0.06 at\% Sc-0.02 at\% REM alloys ( $R E M=D y, E r, G d, S m, Y$, or $Y b)$ aging at $300{ }^{\circ} \mathrm{C}$ are generally similar to that of $\mathrm{Al}-0.08$ at\% Sc alloy. The Al-0.06 at\% Sc alloys microalloyed with $\mathrm{Yb}$ or Gd have much improved creep resistance when compared to binary Al-Sc or ternary $\mathrm{Al}-\mathrm{Sc}-\mathrm{Zr}$ alloys with the same composition and precipitate radius [18]. According to Sawtell and Morris [19,20], addition of $0.3 \mathrm{at} \% \mathrm{Er}, \mathrm{Gd}, \mathrm{Ho}$, or Y improves the tensile strength of $\mathrm{Al}-0.3$ at\% Sc alloys at room temperature. 
In this study, we investigate dilute $\mathrm{Al}-0.24 \mathrm{wt} \% \mathrm{Sc}$ alloys with microalloying addition of $0.07 \mathrm{wt} \% \mathrm{Yb}$ to compare with $\mathrm{Al}-0.28 \mathrm{wt}$ $\% \mathrm{Sc}$ alloy. The effects of substituting $\mathrm{Yb}$ for Sc on the microstructure and the mechanical properties of Al-Sc alloy are investigated by using SEM, TEM, high-resolution TEM and Vickers hardness.

\section{Experimental procedure}

Al-0.28 wt\% Sc and Al-0.24 wt\% Sc-0.07 wt\% Yb alloys were cast by using commercially pure $\mathrm{Al}$ ( 99.83 wt\% purity), Al-2 wt\% Sc master alloy and pure $\mathrm{Yb}$ (99.99 wt\% purity). The alloys were melted in a graphite crucible using a high frequency induction furnace. For each alloy, pure Al was firstly melted at $720^{\circ} \mathrm{C} \pm 5$. Then the Al-2 wt\% Sc master alloy and pure $\mathrm{Yb}$ were added into the melt. The melt was kept at this temperature for $30 \mathrm{~min}$ and stirred with an alumina rod to ensure homogeneity. The molten alloys were poured into cylindrical copper moulds with $16 \mathrm{~mm}$ in diameter and $80 \mathrm{~mm}$ in length and water cooled. The composition of the as-cast alloy was measured by X-ray Fluorescence Spectrometry (Bruker S8 Tiger). The chemical composition of the as-cast alloys is given in Table 1.

In order to study the effect of homogenization treatment and aging temperature on precipitation behaviour and age hardening response, two separate studies were conducted: in one, the as-cast alloys were treated at $640{ }^{\circ} \mathrm{C}$ for $72 \mathrm{~h}$ for homogenization and water quenched to room temperature. The samples were subsequently treated at various temperatures within the range 150$375{ }^{\circ} \mathrm{C}$ for $2 \mathrm{~h}$, followed by water quenching to ambient room temperature; in the other, the same procedure without homogenization treatment was carried out.

In order to evaluate the aging kinetics, isothermal aging without homogenization treatment of the cast samples was carried out. The samples were aged at different temperatures between 300 and $350{ }^{\circ} \mathrm{C}$ for times ranging from $10 \mathrm{~min}$ to 7 days.

Vickers hardness was used to monitor the hardening behaviour. Vickers hardness measurements were performed at room temperature using $30 \mathrm{~kg}$ load and $20 \mathrm{~s}$ dwell time. Eight measurements were performed on each sample. Scanning electron microscopy (SEM) micrographs were obtained on a Nano-SEM-FEI Nova 200 FEG/SEM scanning electron microscope. Transmission electron microscopy (TEM) and high resolution electron microscope (HRTEM), were used to determine the structure and morphological characteristics of the precipitates. The specimens were examined by FEI TECNAI G20 operating at $200 \mathrm{kV}$. Thin foils for transmission electron microscope (TEM) and high resolution electron microscope (HRTEM) observations were sectioned from the alloys under different conditions. The foils were prepared by double-jet electropolishing in a solution of 25\% nitric acid and $75 \%$ methanol solution. In order to determine the average diameter and evaluate the number of precipitates, the TEM micrographs were analysed by Image J software. For each condition, four TEM micrographs at various positions of sample with more than 200 precipitates were selected to measure the precipitate size.

\section{Results and discussion}

\subsection{Age hardening behaviour of the as-cast alloys}

\subsubsection{Effect of homogenization treatment and aging temperatures on} ageing behaviour

The Vickers hardness curves of Al-0.28 wt\% Sc and Al-0.24 wt\% Sc-0.07 wt\% Yb alloys aged at various temperatures within the range $150-375{ }^{\circ} \mathrm{C}$ for $2 \mathrm{~h}$ with and without homogenization treatment are shown in Fig. 1. It is evident that the hardness values of the alloys aged in the as-cast condition are significantly higher than those of the alloys homogenized and aged. In the ascast alloys, Sc and $\mathrm{Yb}$ exist in $\alpha$-Al supersaturated solid solution due to the high cooling rate during solidification. The precipitation of intermetallic particles occurs during the homogenization treatment, reducing the supersaturation level of Sc and $\mathrm{Yb}$ in $\alpha$-Al solid solution. As a consequence, homogenized alloys will have the lower hardening effect due to the lower fraction volume/density of precipitates. Fig. 2 shows SEM micrographs of as-cast and homogenized $\mathrm{Al}-0.24 \mathrm{wt} \% \mathrm{Sc}-0.07 \mathrm{wt} \% \mathrm{Yb}$ samples. In the homogenized samples, several large particles of intermetallic precipitates were formed and heterogeneously distributed in $\alpha$-Al.

Also shown in Fig. 1 is the effect of substituting $0.07 \mathrm{wt} \% \mathrm{Yb}$ for Sc of Al-0.28 wt\% Sc alloy on aging behaviour at various temperatures. The onset of age hardening for both alloys occurs at $200{ }^{\circ} \mathrm{C}$. The precipitates form most rapidly at the temperature range of $300-350^{\circ} \mathrm{C}$, for which the highest hardness values were obtained. In the aging process without homogenization treatment, the Vickers hardness value peaks of $\mathrm{Al}-0.28 \mathrm{wt} \% \mathrm{Sc}$ and $\mathrm{Al}-0.24 \mathrm{wt} \%$ Sc-0.07 wt\% $\mathrm{Yb}$ alloys are $72 \mathrm{HV}$ at $325^{\circ} \mathrm{C}$ and $68 \mathrm{HV}$ at $350{ }^{\circ} \mathrm{C}$, respectively. A decreasing in Vickers hardness is observed for both alloys for temperatures higher than $375^{\circ} \mathrm{C}$ due to the precipitate

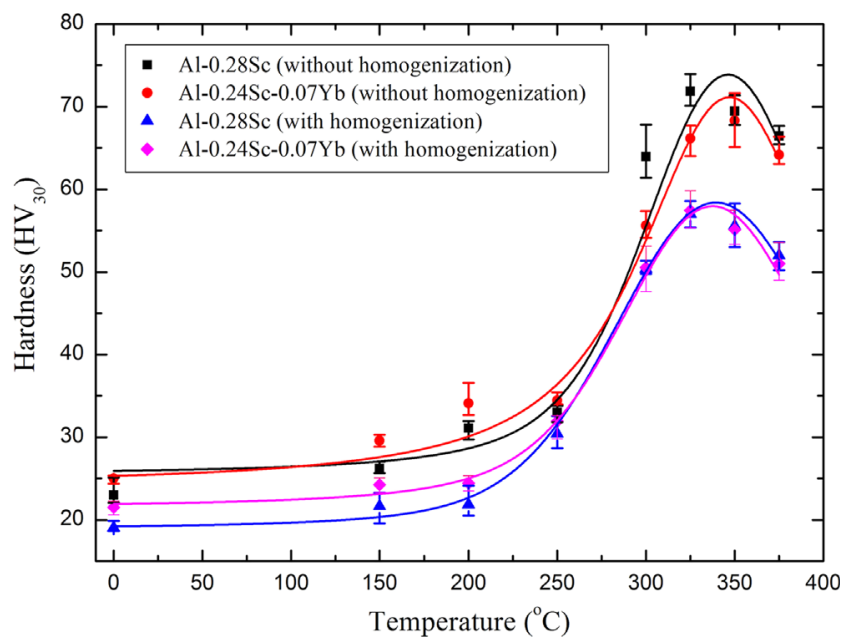

Fig. 1. Vickers hardness curves of $\mathrm{Al}-0.28 \mathrm{wt} \% \mathrm{Sc}, \mathrm{Al}-0.24 \mathrm{wt} \% \mathrm{Sc}-0.07 \mathrm{wt} \% \mathrm{Yb}$ alloys at various aging temperatures with and without previous homogenization treatment.

Table 1

Chemical composition of the as-cast alloys.

\begin{tabular}{|c|c|c|c|c|c|c|c|c|c|c|}
\hline Alloy & Sc & $\mathrm{Yb}$ & $\mathrm{Si}$ & $\mathrm{Fe}$ & $\mathrm{Ni}$ & $\mathrm{Cu}$ & $\mathrm{Ba}$ & Mn & $\mathrm{Ti}$ & $\mathrm{Al}$ \\
\hline \multicolumn{11}{|l|}{$\mathrm{Al}-\mathrm{Sc}$} \\
\hline wt\% & 0.283 & - & 0.383 & 0.130 & 0.010 & 0.007 & 0.060 & 0.010 & 0.009 & Bal \\
\hline at $\%$ & 0.170 & & 0.369 & 0.063 & 0.005 & 0.003 & 0.012 & 0.005 & 0.005 & Bal \\
\hline \multicolumn{11}{|c|}{$\mathrm{Al}-\mathrm{Sc}-\mathrm{Yb}$} \\
\hline wt\% & 0.243 & 0.068 & 0.328 & 0.208 & 0.040 & 0.032 & 0.015 & - & - & Bal \\
\hline at $\%$ & 0.146 & 0.011 & 0.316 & 0.101 & 0.018 & 0.014 & 0.003 & - & - & Bal \\
\hline
\end{tabular}



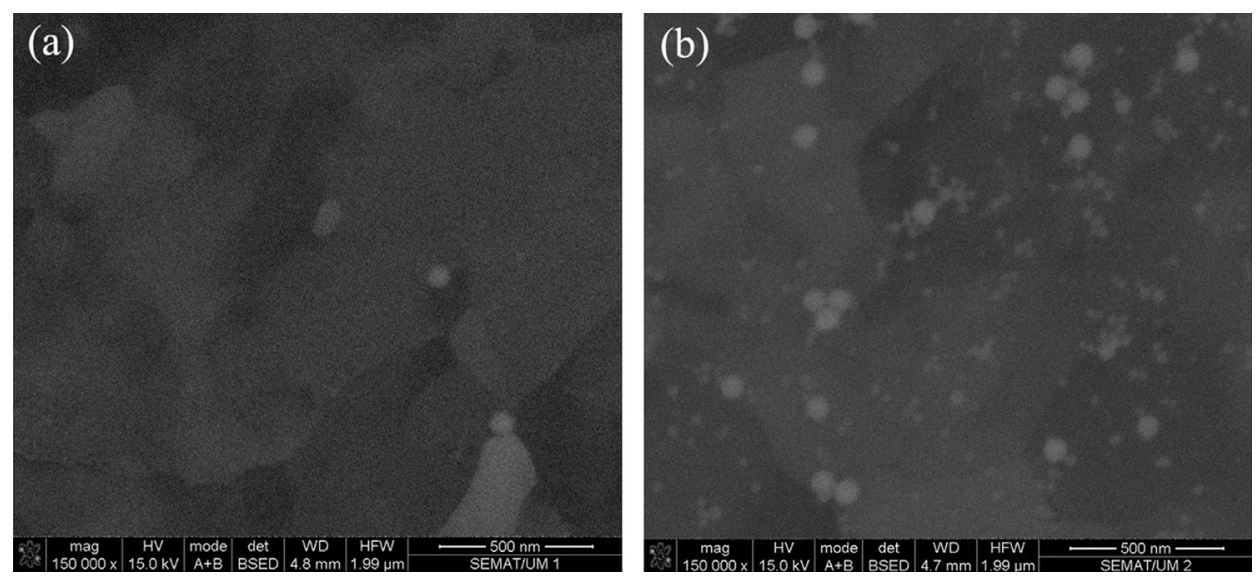

Fig. 2. SEM micrographs of Al-0.24 wt\% Sc-0.07 wt\% Yb alloy: (a) as-cast and (b) homogenization treated.

coarsening. The results showed that the partial replacement of Sc by $\mathrm{Yb}$ did not significantly affect either the kinetics or the peak hardness. Karnesky et al. [17] reported similar effect of $\mathrm{Yb}$ on the hardening response of an Al-0.08 at\% Sc based alloy.

The alloys used in this work present in their composition small contents of other elements, namely $\mathrm{Si}$ and Fe that may have some small influence on the alloys mechanical properties, namely hardness. Nevertheless, the difference between both alloys is very small, suggesting that the relative hardness values have not been influenced by the presence of those elements.

\subsubsection{Isothermal aging behaviour}

The age hardening behaviour of $\mathrm{Al}-0.28 \mathrm{wt} \% \mathrm{Sc}$ and $\mathrm{Al}-0.24 \mathrm{wt}$ $\%$ Sc-0.07 wt\% Yb alloys at aging temperatures of 300, 325 and $350{ }^{\circ} \mathrm{C}$ is shown in Fig. 3. It is quite evident that the $\mathrm{Al}-0.24 \mathrm{wt} \%$ Sc-0.07 wt\% Yb alloy shows the similarity of Vickers hardness and aging behaviour with the Al-0.28 wt\% Sc alloy. All the curves exhibits four different regions: (a) an incubation period; (b) a period with a rapid increase in hardness values where the precipitates nucleate from a supersaturated solid solution and grow; (c) a period of maximum hardness values (peak aging); and (d) over-aging, characterized by a slow decrease in hardness by the precipitates coarsening. The time to reach the hardness value peak decreases when the aging temperature increases from 300 to $350{ }^{\circ} \mathrm{C}$. The Al-0.28 wt\% Sc and $\mathrm{Al}-0.24 \mathrm{wt} \% \mathrm{Sc}-0.07 \mathrm{wt} \% \mathrm{Yb}$ alloys reach the hardness value peak after 20,5 , and $1 \mathrm{~h}$ when aging at 300,325 , and $350{ }^{\circ} \mathrm{C}$, respectively. Higher temperature leads to earlier occurrence of over-aging. In Fig. 3(a), there is no significantly softening due to over-aging for both alloys aged at $300{ }^{\circ} \mathrm{C}$ after 7 days. However, Fig. 3(b) and (c) shows a fast over-aging for both alloys aged at 325 and $350{ }^{\circ} \mathrm{C}$. At these aging temperatures, the hardness drop becomes obviously after reaching the peak values. Higher aging temperature conducts to higher diffusion rate for precipitates nucleation and growth. It accelerates the overaging stage.

\subsection{Evolution of precipitates}

\subsubsection{Precipitate morphologies}

The aging behaviour presented above is controlled by the alloys microstructure. In order to correlate the observed hardening with microstructures, TEM and HRTEM observations were performed on samples at different processing states to reveal the evolution of the precipitates.

The TEM micrographs of Al-0.28 wt\% Sc and Al-0.24 wt\% Sc $-0.07 \mathrm{wt} \% \mathrm{Yb}$ alloys aged at $325{ }^{\circ} \mathrm{C}$ for $5 \mathrm{~h}, 325{ }^{\circ} \mathrm{C}$ for 7 days, and $350{ }^{\circ} \mathrm{C}$ for 7 days are shown in Fig. 4, respectively. In order to observe more clearly the morphology of precipitates, higher magnification of TEM micrographs with bright-field and darkfield techniques are exhibited in Fig. 5. The micrographs show the approximately spheroidal $\mathrm{Al}_{3} \mathrm{Sc}$ and $\mathrm{Al}_{3}(\mathrm{Sc}, \mathrm{Yb})$ precipitates, uniformly distributed throughout the $\alpha$-Al matrix. The $\mathrm{Al}_{3}(\mathrm{Sc}, \mathrm{Yb})$ precipitates in $\mathrm{Al}-0.24 \mathrm{wt} \% \mathrm{Sc}-0.07 \mathrm{wt} \% \mathrm{Yb}$ alloy could be $\mathrm{Al}_{3} \mathrm{Sc}$, $\mathrm{Al}_{3}\left(\mathrm{Sc}_{1-x} \mathrm{Yb}_{x}\right)$ (Sc-rich composition), $\mathrm{Al}_{3}\left(\mathrm{Yb}_{1-x} \mathrm{Sc}_{x}\right)$ (Yb-rich composition), or $\mathrm{Al}_{3} \mathrm{Yb}$ precipitates. There are no signs of coherency loss that can be observed in Figs. 4 and 5. The precipitates in both alloys aged at the higher temperature $\left(350^{\circ} \mathrm{C}\right)$ for long holding time (7 days) still remain coherent with $\alpha$-Al matrix. The precipitate diameter of both alloys at the different aging conditions was measured and the corresponding results are presented in Table 2. After aging at $300{ }^{\circ} \mathrm{C}$ for 7 days the average diameter of $\mathrm{Al}_{3} \mathrm{Sc}$ precipitate is $5.6 \mathrm{~nm}$ and that of $\mathrm{Al}_{3}(\mathrm{Sc}, \mathrm{Yb})$ precipitate is $5.9 \mathrm{~nm}$. The presence of very small precipitates after long aging time indicates that coarsening occurred very slowly at $300{ }^{\circ} \mathrm{C}$. In combination with hardness results presented in Section 3.1, it can be seen that the strongest hardening effects of both alloys was achieved at aging temperature of $300{ }^{\circ} \mathrm{C}$. When alloys were aged at $325{ }^{\circ} \mathrm{C}$, the average diameter is $4.3 \mathrm{~nm}$ for the $\mathrm{Al}_{3} \mathrm{Sc}$ precipitate and $4.5 \mathrm{~nm}$ for the $\mathrm{Al}_{3}(\mathrm{Sc}, \mathrm{Yb})$ precipitates at the aging peak. With prolonged aging times, after 7 days the average diameter of $\mathrm{Al}_{3} \mathrm{Sc}$ and $\mathrm{Al}_{3}(\mathrm{Sc}, \mathrm{Yb})$ precipitates slowly increase to 8.4 and $8.8 \mathrm{~nm}$, respectively. At the temperature of $350{ }^{\circ} \mathrm{C}$ and 7 days aging, the average diameter of $\mathrm{Al}_{3} \mathrm{Sc}$ and $\mathrm{Al}_{3}(\mathrm{Sc}, \mathrm{Yb})$ precipitates are 13.7 and $15.4 \mathrm{~nm}$, respectively. The TEM images show a smaller number of larger size precipitates due to the coarsening process. The average precipitates size of $\mathrm{Al}-0.24 \mathrm{wt} \% \mathrm{Sc}-0.07 \mathrm{wt} \% \mathrm{Yb}$ alloy is slightly higher than that of $\mathrm{Al}-0.28 \mathrm{wt} \% \mathrm{Sc}$ alloys for all aging conditions. Thus, it suggests that $\mathrm{Yb}$ did not affect the coarsening rate of Al-Sc alloy.

The precipitates size distribution (PSDs) of Al-0.28 wt\% Sc and Al-0.24 wt\% Sc-0.07 wt\% Yb alloys aged at $325{ }^{\circ} \mathrm{C}$ and $350{ }^{\circ} \mathrm{C}$ for 7 days is illustrated in Fig. 6. The PSDs of $\mathrm{Al}-0.28 \mathrm{wt} \% \mathrm{Sc}$ aged at $325^{\circ} \mathrm{C}$ for 7 days showed more narrow width in comparison with $\mathrm{Al}-0.24 \mathrm{wt} \% \mathrm{Sc}-0.07 \mathrm{wt} \% \mathrm{Yb}$ alloys at the same aging condition. The precipitates diameter ranges of Al-0.28 wt\% Sc and Al-0.24 wt \% Sc-0.07 wt\% Yb alloys are 7-10.5 and 5-12 nm, respectively. The PSDs of both alloys aged at $350{ }^{\circ} \mathrm{C}$ for 7 days exhibited a similar width. The precipitates diameter ranges of $\mathrm{Al}-0.28 \mathrm{wt} \% \mathrm{Sc}$ and $\mathrm{Al}-0.24 \mathrm{wt} \% \mathrm{Sc}-0.07 \mathrm{wt} \% \mathrm{Yb}$ alloys at this aging condition are 10-18 and $12-20 \mathrm{~nm}$, respectively.

Precipitates in Al-0.28 wt\% Sc and Al-0.24 wt\% Sc-0.07 wt\% Yb alloys at aging peak and the most coarsened stage were deeply studied by HRTEM technique. The HRTEM images of both alloys 
a

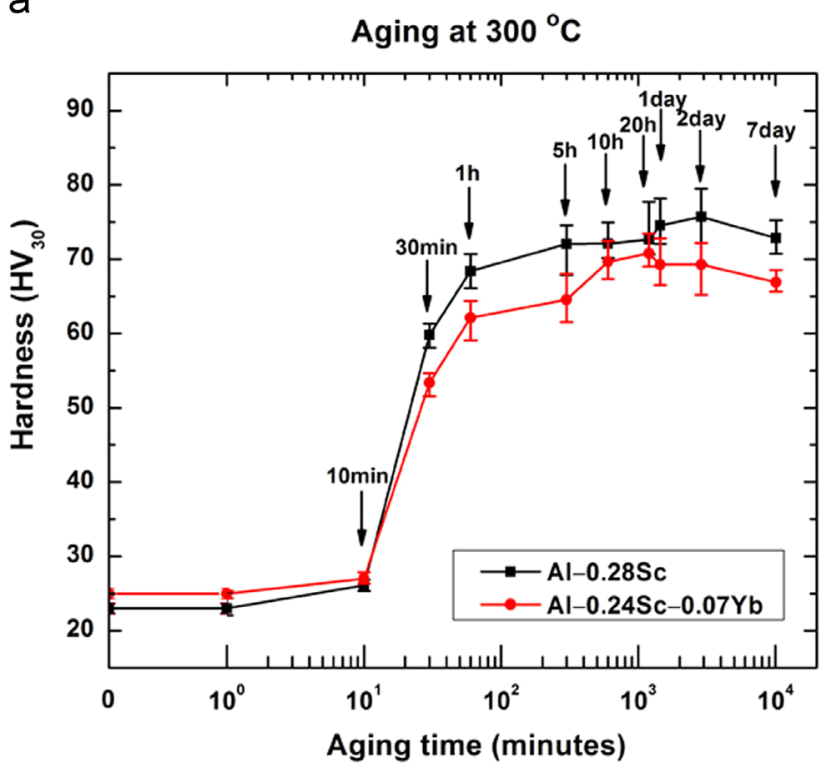

b

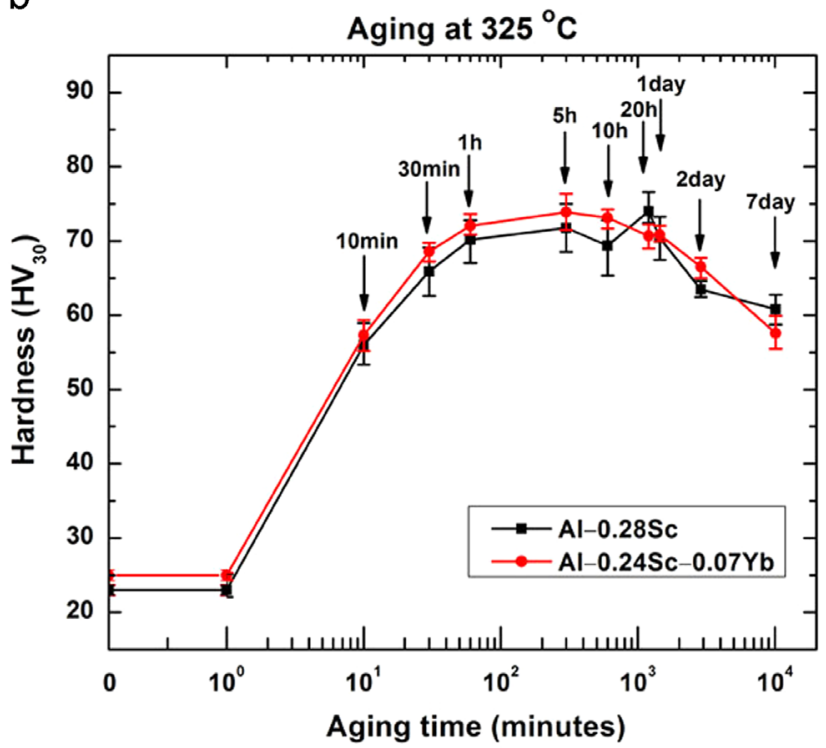

C

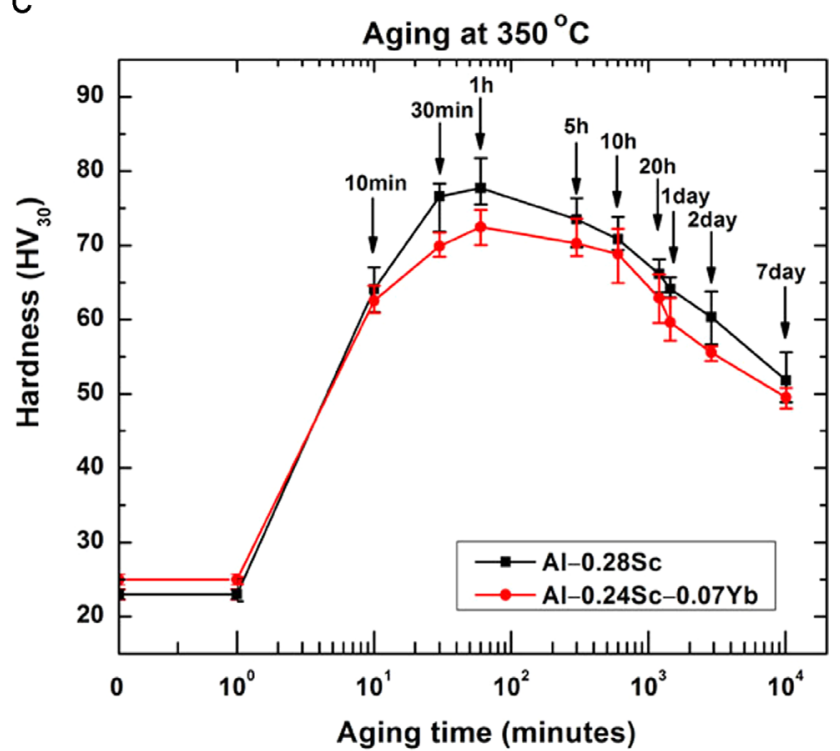

Fig. 3. Isothermal ageing curves of $\mathrm{Al}-0.28 \mathrm{wt} \% \mathrm{Sc}$ and $\mathrm{Al}-0.24 \mathrm{wt} \% \mathrm{Sc}-0.07 \mathrm{wt} \% \mathrm{Yb}$ alloys at: (a) $300{ }^{\circ} \mathrm{C}$; (b) $325{ }^{\circ} \mathrm{C}$; (c) $350{ }^{\circ} \mathrm{C}$.

aged at $325^{\circ} \mathrm{C}$ for $5 \mathrm{~h}$ and $350{ }^{\circ} \mathrm{C}$ for 7 days are shown in Fig. 7 . Through fast Fourier transform (FFT) analysis, the [011] zone axis orientation was found to fit well to the simulation of the reciprocal lattice section at the orientation. The FFT images show the reflections from (100) and (011) of $\mathrm{Ll}_{2} \mathrm{Al}_{3} \mathrm{Sc}$ and $\mathrm{Al}_{3}(\mathrm{Sc}, \mathrm{Yb})$ precipitates and the reflections from (200), $(0 \overline{2} 2)$, and (1 $1 \overline{1} 1)$ of $\alpha$-Al. The interface between the precipitates and the $\alpha$-Al matrix remained coherent in both alloys even after aging at $350{ }^{\circ} \mathrm{C}$ for 7 days. There are no interfacial misfit dislocations in the HRTEM images, which conducts fully coherency of precipitates. Fig. 7 (a) and (b) shows the precipitates morphology of Al-0.28 wt\% Sc and $\mathrm{Al}-0.24 \mathrm{wt} \% \mathrm{Sc}-0.07 \mathrm{wt} \% \mathrm{Yb}$ alloys aged at $325^{\circ} \mathrm{C}$ for $5 \mathrm{~h}$. The images show small precipitates with diameter less than $5 \mathrm{~nm}$. The larger size and more obvious morphologies of precipitates are observed in Fig. 7(c) and (d) corresponding to both alloys aged at $350{ }^{\circ} \mathrm{C}$ for 7 days. The $\mathrm{Al}_{3} \mathrm{Sc}$ precipitates in Al-0.28 wt\% Sc alloy have a facetted shape that corresponds to a great rhombicuboctahedron predicted by Marquis et al. [1]. Facets are parallel to the
$\{100\}$ and $\{0 \overline{1} 1\}$ planes. The precipitates average diameter is $18.1 \mathrm{~nm}$, while the $\mathrm{Al}_{3}(\mathrm{Sc}, \mathrm{Yb})$ precipitate in $\mathrm{Al}-0.24 \mathrm{wt} \% \mathrm{Sc}-$ $0.07 \mathrm{wt} \% \mathrm{Yb}$ alloy exhibits an approximately spheroidal shape with $18.5 \mathrm{~nm}$ diameter. The presence of $\mathrm{Yb}$ decreases the amount of faceting parallel to the $\{100\}$ and $\{0 \overline{1} 1\}$ and changes the morphology of precipitates into a more spheroidal shape.

\subsubsection{Coarsening behaviour}

The coarsening behaviour of spherical precipitates in binary alloys was predicted by The Lifshitz-Slyozov-Wagner (LSW) model base on volume diffusion theory $[21,22]$. The Ostwald ripening of spherical precipitates was developed in concentrated multicomponent alloys by Umantsev and Olsan [23] and more detailed in ternary alloys, allowing for capillary effects by Kuehmann and Voorhees (KV) [24]. According to the KV model, the coarsening behaviour of precipitates was analysed through the 
a

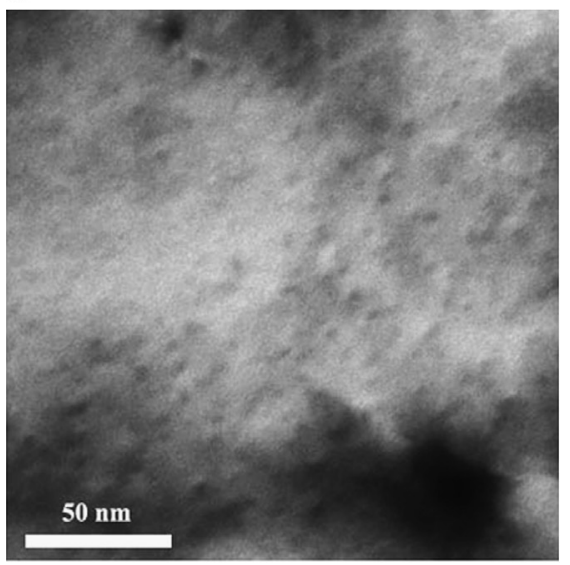

b

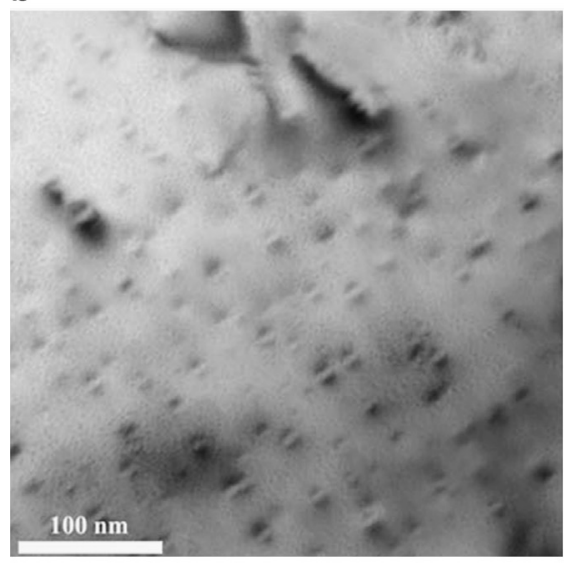

C

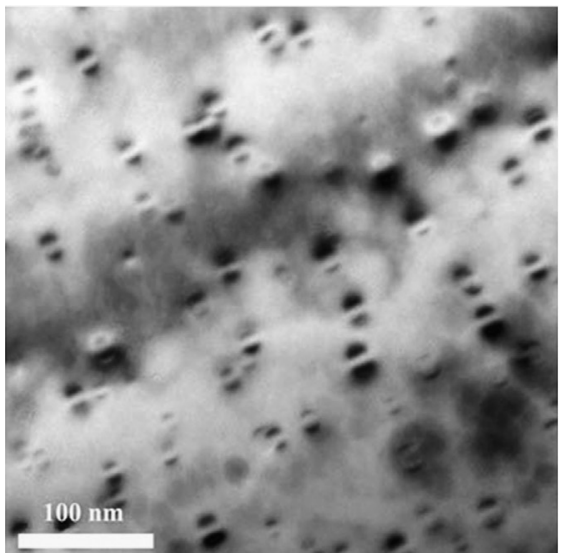

d

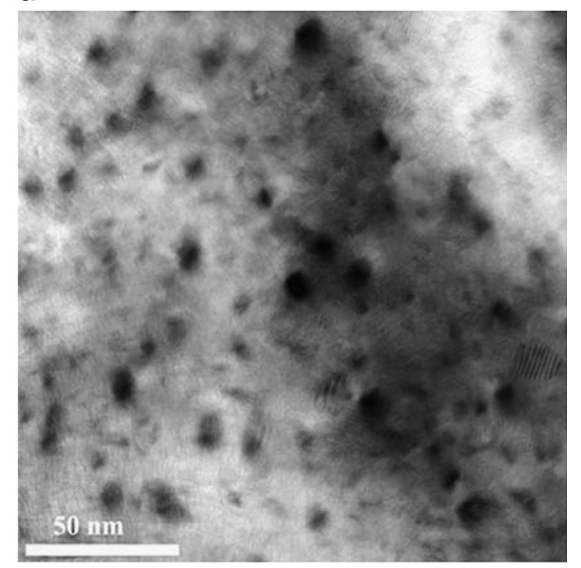

e

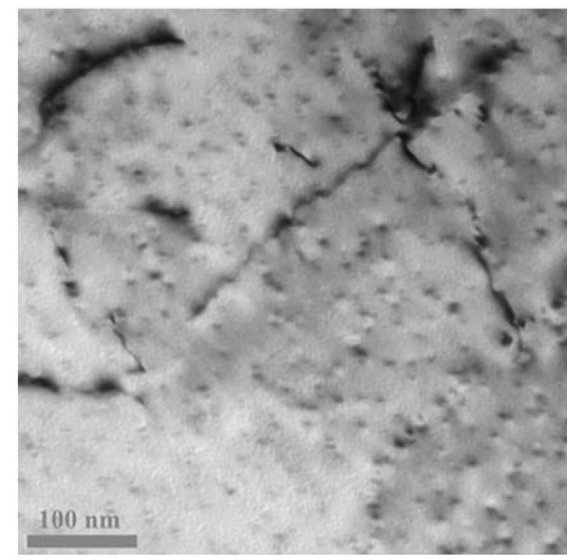

f

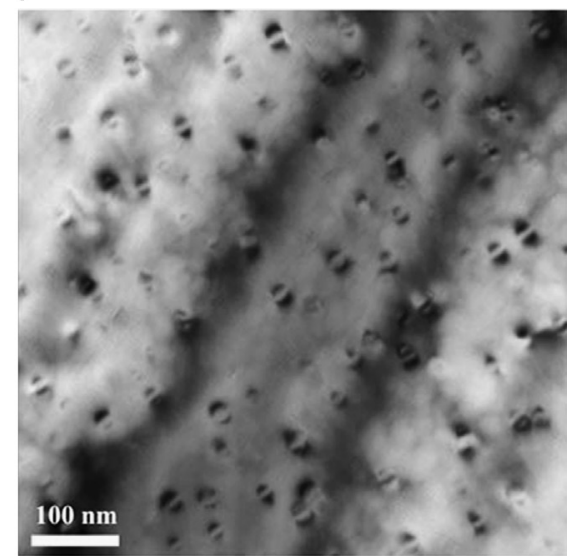

Fig. 4. TEM micrographs of Al-0.28 wt\% Sc (a-c) and Al-0.24 wt\% Sc-0.07 wt\% Yb (d-f) alloys aged at $325^{\circ} \mathrm{C}$ for 5 h, $325{ }^{\circ} \mathrm{C}$ for 7 days, and $350{ }^{\circ} \mathrm{C}$ for 7 days.

following equation:

$\langle R(t)\rangle^{n}-\left\langle R\left(t_{0}\right)\right\rangle^{n}=K\left(t-t_{0}\right)$

where $K$ is a coarsening rate constant, $\langle R(t)\rangle$ is the average precipitate radius at time $t,\left\langle R\left(t_{0}\right)\right\rangle$ is the average precipitate radius at the onset of quasi-stationary coarsening at time $t_{0}$, and $n$ is the inverse time exponent. Eq. (1) could be applied for both binary alloy (Al-0.28 wt\% Sc) and ternary alloy (Al-0.24 wt\% Sc-0.07 wt\% $\mathrm{Yb})$ with different coarsening rate constant. It was assumed that $\left\langle R\left(t_{0}\right)\right\rangle^{n}$ and $t_{0}$ is much smaller than $\langle R(t)\rangle^{n}$ and $t$, Eq. (1) became [25,26]:

$\langle R(t)\rangle^{n}=K t$
A $\log -\log$ plot of Eq. (2) reveals a slope of $1 / n$ as following equation:

$\log \langle R(t)\rangle=\frac{1}{n} \log t+\frac{1}{n} \log K$

This slope is known as a time exponent of coarsening and often reported to indicate the coarsening behaviour of precipitates. By applying the KV model to the $\mathrm{Al}-0.28 \mathrm{wt} \% \mathrm{Sc}$ and $\mathrm{Al}-0.24 \mathrm{wt}$ $\%$ Sc-0.07 wt\% $\mathrm{Yb}$ alloys aged at $325{ }^{\circ} \mathrm{C}$, the time exponents of coarsening $1 / n$ was calculated and showed the same value of 0.19 for both alloys. This value indicated that the precipitate coarsening behaviour of both investigated alloys is similar to the Al-0.18 at\% 


\section{a}

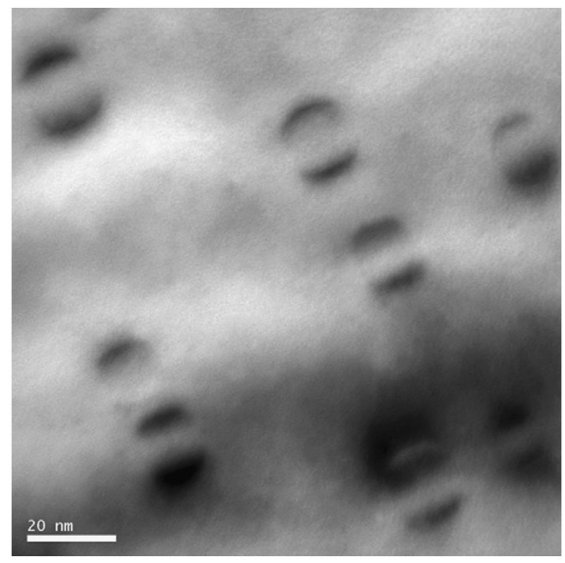

b

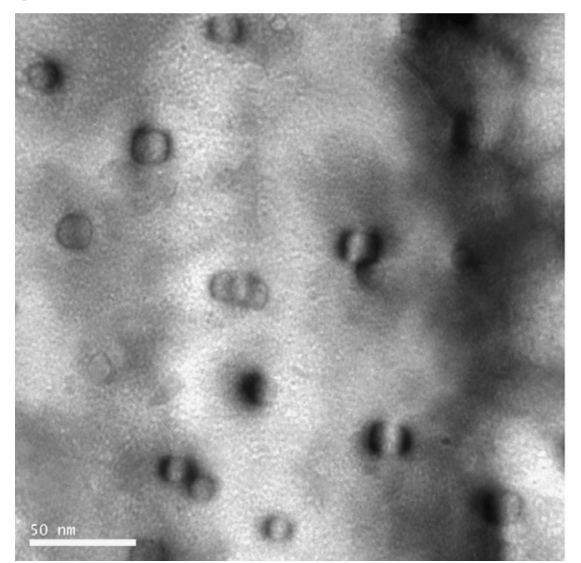

C

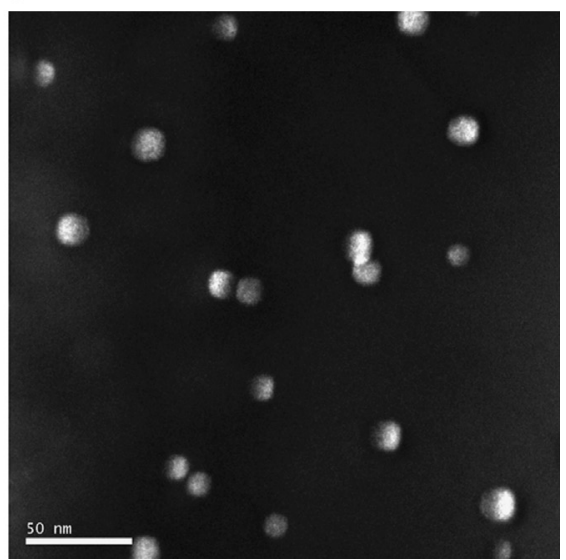

Fig. 5. TEM micrographs of $\mathrm{Al}-0.28 \mathrm{wt} \% \mathrm{Sc}(\mathrm{a})$ and $\mathrm{Al}-0.24 \mathrm{wt} \% \mathrm{Sc}-0.07 \mathrm{wt} \% \mathrm{Yb}\left(\mathrm{b}\right.$ and c) alloys aged at $350{ }^{\circ} \mathrm{C}$ for 7 days: (a) and (b) bright-field TEM image; and (c) darkfield TEM image.

Table 2

Average precipitate diameter and hardness of Al-0.28 wt\% Sc and Al-0.24 wt\% Sc-0.07 wt\% Yb alloys.

\begin{tabular}{|c|c|c|c|c|}
\hline \multirow[t]{2}{*}{ Aging condition } & \multicolumn{2}{|l|}{$\mathrm{Al}-0.28 \mathrm{wt} \% \mathrm{Sc}$} & \multicolumn{2}{|l|}{$\mathrm{Al}-0.24 \mathrm{wt} \% \mathrm{Sc}-0.07 \mathrm{wt} \% \mathrm{Yb}$} \\
\hline & Precipitate diameter (nm) & Hardness - $\mathrm{HV}_{30}$ & Precipitate diameter (nm) & Hardness $-\mathrm{HV}_{30}$ \\
\hline $300{ }^{\circ} \mathrm{C}, 7$ days & $5.6 \pm 0.5$ & $73 \pm 2$ & $5.9 \pm 0.7$ & $67 \pm 2$ \\
\hline $325^{\circ} \mathrm{C}, 5 \mathrm{~h}$ & $4.3 \pm 0.2$ & $72 \pm 3$ & $4.5 \pm 0.8$ & $74 \pm 3$ \\
\hline $325^{\circ} \mathrm{C}, 7$ days & $8.4 \pm 0.9$ & $61 \pm 2$ & $8.8 \pm 1.8$ & $58 \pm 2$ \\
\hline $350^{\circ} \mathrm{C}, 7$ days & $13.7 \pm 1.9$ & $52 \pm 3$ & $15.4 \pm 1.8$ & $50 \pm 1$ \\
\hline
\end{tabular}

Sc alloy aged at $300{ }^{\circ} \mathrm{C}((1 / n)=0.18)$ referred by Marquis et al. $[1,25]$ and $\mathrm{Al}-0.06 \mathrm{at} \% \mathrm{Sc}-0.02 \mathrm{at} \% \mathrm{Yb}\left(\right.$ at\%) alloy aged at $300{ }^{\circ} \mathrm{C}$ $((1 / n)=0.18)$ referred by Van Dalen et al. [27].

\subsection{Precipitation hardening mechanisms}

The evolution of precipitates and corresponding hardness at different aging conditions is presented in Table 2. According to Hyland et al. [28] and Marquis et al. [2], the volume fraction of precipitate is approximately constant for $\mathrm{Al}-\mathrm{Sc}$ alloys aged at various temperatures from $275^{\circ} \mathrm{C}$ to $400{ }^{\circ} \mathrm{C}$ after long enough aging time (longer than $10,000 \mathrm{~s}$ at $288^{\circ} \mathrm{C}$ and $2000 \mathrm{~s}$ at $343^{\circ} \mathrm{C}$ ). On this work the alloys were aged at 300,325 , and $350{ }^{\circ} \mathrm{C}$ for $5 \mathrm{~h}$ and 7 days. For these conditions and according to the findings of Hyland and Marquis we can assume that the volume fraction of precipitates is constant. The precipitation hardening is typically understood through the cutting mechanism which dislocations cut through precipitates and the Orowan bypass mechanism which dislocations bow or loop precipitates. According to the experimental data from the study about precipitation strengthening in Al-0.3 wt\% Sc alloy, Marquis et al. [2] predicted a transition from cutting mechanism to Orowan bypass mechanism at a precipitate diameter of $4.2 \mathrm{~nm}$. The strength of alloy is controlled by the cutting mechanism for smaller sizes, and the Orowan bypass mechanism for larger sizes of precipitates which higher precipitate diameter results in lower hardness. Table 2 showed a maximum hardness around $73\left(\mathrm{HV}_{30}\right)$ at a precipitate diameter from 4.3 to $5.6 \mathrm{~nm}$ for both alloys. It sharply decreases to $\mathrm{HV}_{30}=50$ when the average diameter of precipitate increases to $13.7-15.4 \mathrm{~nm}$. This result is in a good agreement with above theory and the result of Marquis et al. [2]. 

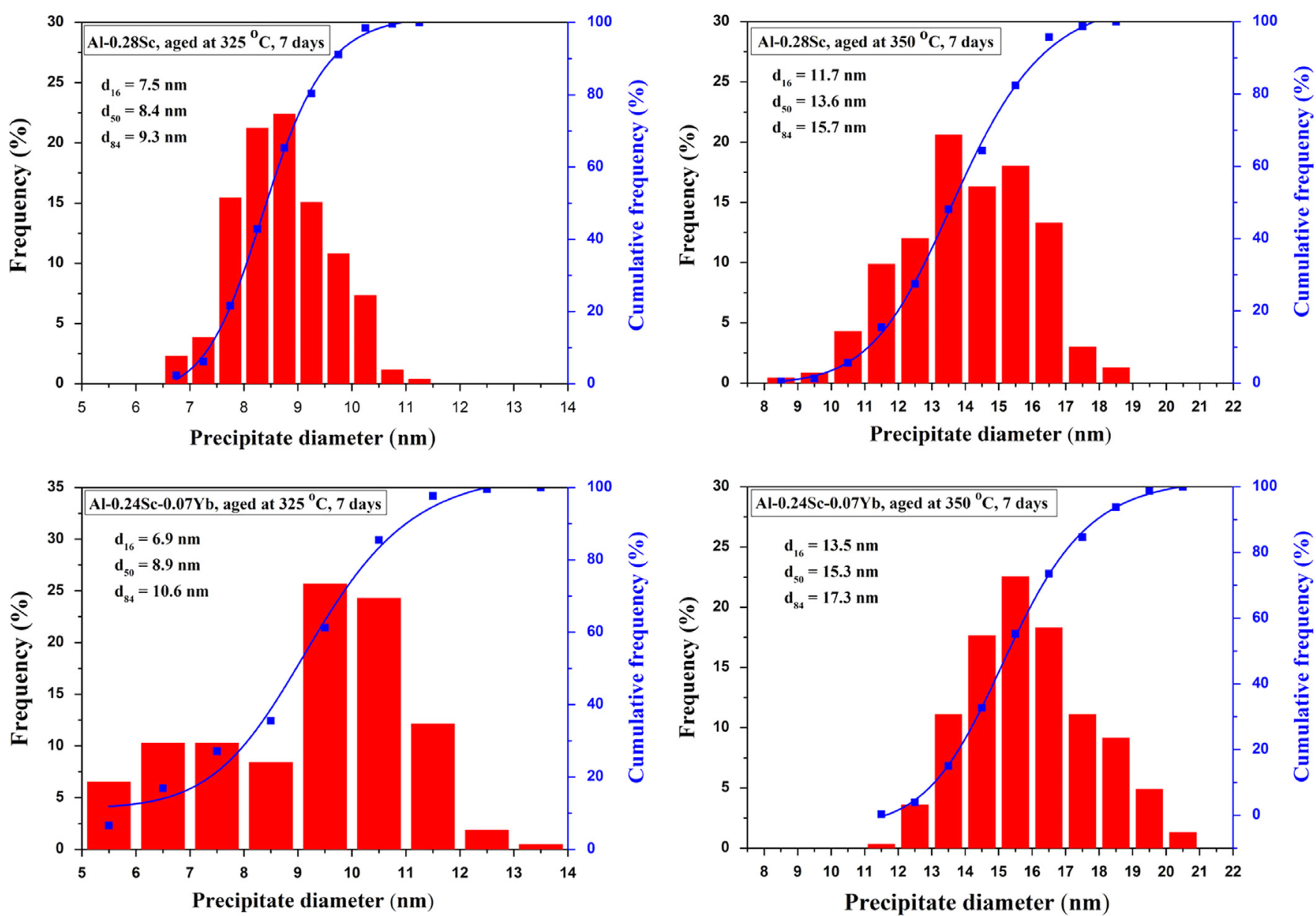

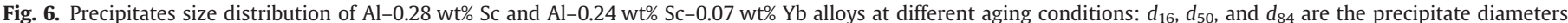
corresponding to $16 \%, 50 \%$, and $84 \%$ cumulative undersize particle size distribution.
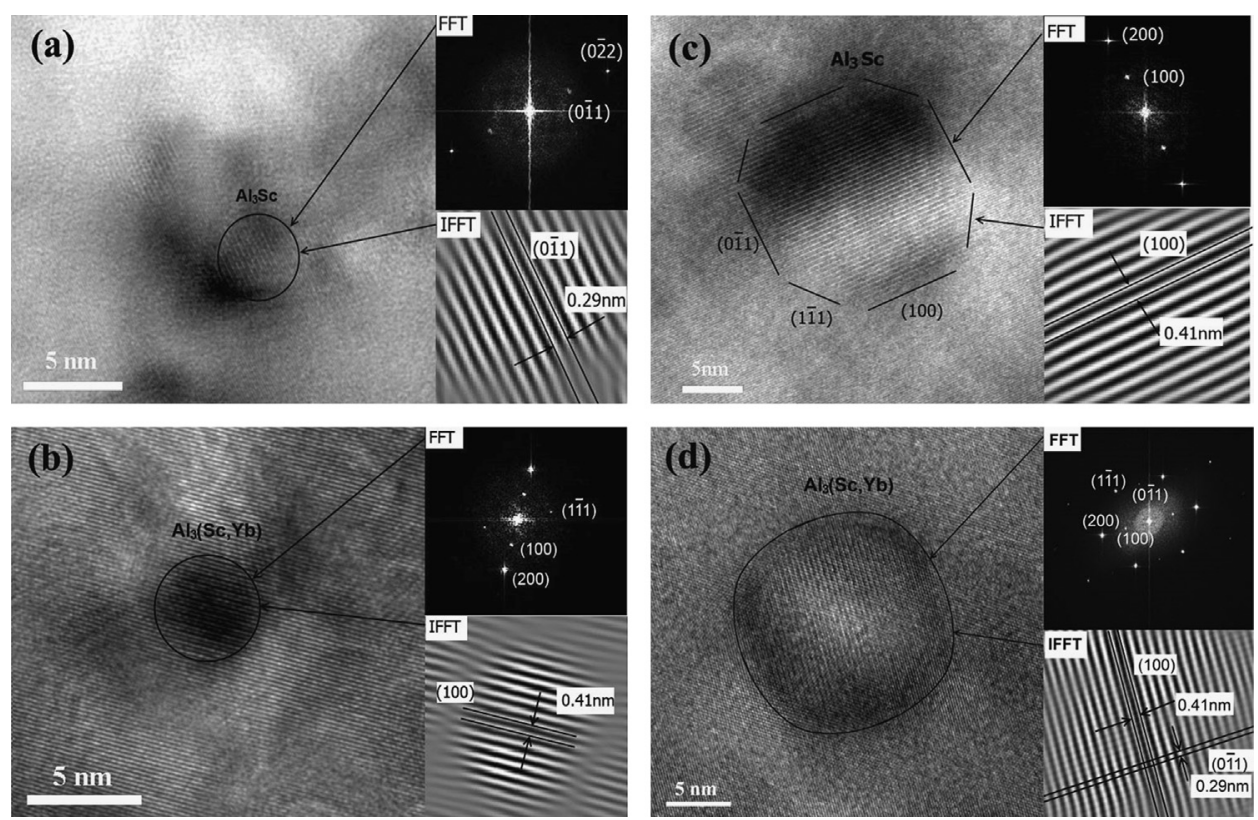

Fig. 7. High-resolution TEM images of $\mathrm{Al}-0.28 \mathrm{wt} \% \mathrm{Sc}(\mathrm{a}-\mathrm{c})$ and $\mathrm{Al}-0.24 \mathrm{wt} \% \mathrm{Sc}-0.07 \mathrm{wt} \% \mathrm{Yb}(\mathrm{b}-\mathrm{d})$ alloys aged at $325^{\circ} \mathrm{C}$ for $5 \mathrm{~h}$ and $350^{\circ} \mathrm{C}$ for 7 days. 


\section{Conclusions}

The similarity of microstructure, hardness and aging behaviour of $\mathrm{Al}-0.24 \mathrm{wt} \% \mathrm{Sc}-0.07 \mathrm{wt} \% \mathrm{Yb}$ alloy in comparison with $\mathrm{Al}-0.28 \mathrm{wt} \% \mathrm{Sc}$ alloy was shown in this investigation. It indicates that the substitution of $0.07 \mathrm{wt} \% \mathrm{Yb}$ for more expensive Sc in the Al- $0.28 \mathrm{wt} \% \mathrm{Sc}$ alloy is possible. Some final characteristics of $\mathrm{Al}-0.28 \mathrm{wt} \% \mathrm{Sc}$ and $\mathrm{Al}-0.24 \mathrm{wt} \% \mathrm{Sc}-0.07 \mathrm{wt} \% \mathrm{Yb}$ alloys were concluded below:

- The hardness values of both alloys aged without homogenization treatment are significantly higher than those of alloys aged after homogenization treatment.

- The approximately spheroidal $\mathrm{Al}_{3} \mathrm{Sc}$ and $\mathrm{Al}_{3}(\mathrm{Sc}, \mathrm{Yb})$ precipitates were uniformly distributed throughout the $\alpha$-Al matrix. The precipitates remain fully coherent with $\alpha$-Al matrix even after aging at high temperature for long time.

- With the aging temperature of $325^{\circ} \mathrm{C}$, the average diameter is $4.3 \mathrm{~nm}$ for $\mathrm{Al}_{3} \mathrm{Sc}$ precipitates and $4.5 \mathrm{~nm}$ for $\mathrm{Al}_{3}(\mathrm{Sc}, \mathrm{Yb})$ precipitates at the aging peak. At the temperature of $350{ }^{\circ} \mathrm{C}$ and 7 days aging, the average diameter of $\mathrm{Al}_{3} \mathrm{Sc}$ and $\mathrm{Al}_{3}(\mathrm{Sc}, \mathrm{Yb})$ precipitates are 13.7 and $15.4 \mathrm{~nm}$, respectively

- The $\mathrm{Al}_{3} \mathrm{Sc}$ precipitates of $\mathrm{Al}-0.28 \mathrm{wt} \% \mathrm{Sc}$ alloy show the facetted shape that are similar with great rhombicuboctahedron shape. While the $\mathrm{Al}_{3}(\mathrm{Sc}, \mathrm{Yb})$ precipitates of $\mathrm{Al}-0.24 \mathrm{wt} \% \mathrm{Sc}-0.07 \mathrm{wt} \%$ $\mathrm{Yb}$ alloy show an approximately spheroidal shape.

\section{Acknowledgements}

This research was supported by The Project Bridging The Gap, funded by the Erasmus Mundus External Cooperation Window Program. Acknowledgements also to the University of Minho, for the provision of research facilities

\section{References}

[1] E.A. Marquis, D.N. Seidman, Acta Mater. 49 (2001) 1909-1919.

[2] E.A. Marquis, D.N. Seidman, D.C. Dunand, Acta Mater. 51 (2003) 285-287 (Acta Mater. 50 (2002) 4021-4035).

[3] J. Røyset, N. Ryum, Int. Mater. Rev, 50 (2005) 19-44.

[4] L.S. Toropova, D.G. Eskin, M.L. Kharakterova, T.V. Dobatkina, Advanced Aluminum Alloys Containing Scandium: Structure and Properties, Gordon and Breach, Amsterdam, The Netherlands, 1998.

[5] S. Iwamura, Y. Miura, Acta Mater. 52 (2004) 591-600.

[6] M.Y. Drits, L.B. Ber, Y.G. Bykov, L.S. Toropova, G.K. Anastas'eva, Phys. Met. Metallogr. 57 (1984) 118-126.

[7] I.C.f.D. Data, Using the Powder Diffraction File, International Centre for Diffraction Data, 1996.

[8] Y. Harada, D.C. Dunand, Mater. Sci. Eng.: A 329-331 (2002) 686-695.

[9] Y. Harada, D.C. Dunand, Scr. Mater. 48 (2003) 219-222.

[10] L.S. Kramer, W.T. Tack, M.T. Fernandes, Adv. Mater. Processes 152 (1997) 23-24.

[11] M.J. Jones, F.J. Humphreys, Acta Mater. 51 (2003) 2149-2159.

[12] V. Ocenasek, M. Slamova, Mater. Charact. 47 (2001) 157-162.

[13] O.I. Zalutskaya, V.G. Kontseyoy, N.I. Karamishev, V.R. Ryabov, I.I. Zalutskii, Dopov. Akad. Nauk. Ukr. RSR (1970) 751, http://arc.nucapt.northwestern.edu/ refbase/show.php?record=293.

[14] A. Palenzona, J. Less Common Met. 29 (1972) 289-292.

[15] L.F. Mondolfo, Aluminum Alloys: Structure and Properties, Butterworths, London, 1976.

[16] E.A. Marquis, D.C. Dunand, Scr. Mater. 47 (2002) 503-508.

[17] R.A. Karnesky, M.E. van Dalen, D.C. Dunand, D.N. Seidman, Scr. Mater. 55 (2006) 437-440.

[18] M.E. Dalen, D.C. Dunand, D.N. Seidman, J. Mater. Sci. 41 (2006) 7814-7823.

[19] R.R. Sawtell, J.W. Morris, Dispersion Strengthened Aluminum Alloys, TMS, Warrendale, PA, 1988.

[20] R.R. Sawtell, Exploratory alloy development in the system Al-Sc-X, University of California, Berkeley, 1988.

[21] C.Z. Wagner, Z. Elektrochem, Angew. Phys. Chem. 65 (1961) 581.

[22] I.M. Lifshitz, V.V. Slyozov, J. Phys. Chem. Solids 19 (1961) 35-50.

[23] A. Umantsev, G.B. Olson, Scr. Metall. Mater. 29 (1993) 1135-1140.

[24] C.J. Kuehmann, P.W. Voorhees, Metall. Mater. Trans. A 27 (1996) 937-943.

[25] E.A. Marquis, D.N. Seidman, Acta Mater. 53 (2005) 4259-4268.

[26] J. Lai, Z. Zhang, X.G. Chen, J. Alloys Compd. 552 (2013) 227-235.

[27] M.E. Van Dalen, D.C. Dunand, D.N. Seidman, Acta Mater. 59 (2011) 5224-5237.

[28] R.W. Hyland, Mater. Trans. A 23 (1992) 1947-1955. 